\title{
Reading biomedical English: method and materials
}

\section{Lourdes Divasson}

\section{(2) OpenEdition \\ Journals}

Electronic version

URL: http://journals.openedition.org/asp/4227

DOI: $10.4000 /$ asp. 4227

ISSN: 2108-6354

Publisher

Groupe d'étude et de recherche en anglais de spécialité

\section{Printed version}

Date of publication: 1 February 1994

Number of pages: $31-37$

ISSN: 1246-8185

\section{Electronic reference}

Lourdes Divasson, « Reading biomedical English: method and materials », ASp [Online], 3 | 1994, Online since 19 February 2014, connection on 30 April 2019. URL : http://journals.openedition.org/asp/4227 ; DOI : 10.4000/asp.4227

This text was automatically generated on 30 April 2019.

Tous droits réservés 


\title{
Reading biomedical English: method and materials
}

\author{
Lourdes Divasson
}

1 English language is indispensable for scientists, professionals or technicians who wish to keep pace with the swift development of Science and Technology. This is certainly so in the Health Sciences field. For the latter the need to know the language has become increasingly important. Nowadays it is not enough to be capable of translating a biomedical text, it is also necessary to have a good command of English comprehension and oral production as well as to be able to write scientific prose, especially if one hopes to reach an international readership.

2 Unfortunately in many Faculties of Medicine the amount of hours assigned to the teaching of English, coupled with the excessive number of students per class, makes the teaching of all these language skills difficult. Therefore, frequently, the lecturer can only aim to give a scientific reading course.

3 Nevertheless, this is no minor aim if recall Maher's claim (1987) after revising thousands of articles from the Index Medicus, that the number of those written in English between 1960 and 1983 had risen by 19\%. Approximately 3,000,000 papers are published every year in seven different languages in 20,000 journals. About $80 \%$ of these are written in English (Salager-Meyer 1991). Consequently, fluency in reading skills is the minimum requirement needed to be able to publications in countries where English is not the mother tongue (Maher 1987).

4 Reading biomedical English effectively is a study skill highly relevant to the needs of medical students. It is also absolutely essential to every doctor regardless of his particular field of research or where he carries out his works -treatment, disease prevention etc.

5 The aim of a reading English for Medical Purposes (EMP) course is to teach students the necessary skills to retrieve information from a written text. This means that we should follow what Johns and Davies (1983) call a TAVI approach, i.e., to consider the text as a "vehicle for information" rather than the TALO principle or text as a "linguistic object". For the TAVI approach the focus centres on recognizing main points of information and 
meaning rather than on grammar and lexis, although this does not mean that these aspects can be forgotten, as we will see later.

The problem with understanding texts is due not only to the unknown vocabulary or the difficulty of certain syntactic structures but to students' lack of experience with reading professional literature. Given that there are three main types of medical prose Textbooks, Journals and Occupational the reading material to be provided will be taken from these sources.

7 Students should start by identifying each one and describing their surface structure patterning, which means they must learn to recognize the basic intellectual structure, on rules based on the analysis of isolated sentences.

8 Textbooks are the first genre undergraduates are most likely to face in view of the fact that many lecturers assign bibliographies in English. They represent a very good starting point to familiarize the student with scientific prose. The choice of some chapters from subjects they are taking, such as Physiology or General Pathology always proves highly positive, as it is generally agreed that students' English reading proficiency is linked to their knowledge of the subject-matter they are dealing with. If we choose, for instance, a chapter from a manual on body systems we should emphasize its rhetorical organisation as follows:

Definition, Organs it comprises, Shape, size, location and function, Physiology, Common related ailments

9 If the text to be studied is one of the Occupational English type, a case history, for example, we should stress its main structure:

Personal details, Clinical history, Present complaint, Physical examination,

Analysis, Diagnosis, Treatment, Follow-up

10 With regard to Journals on medical research -clinical, epidemiological, etc.- it is important to distinguish between the three main types of medical English scholarly papers: research papers, reviews and case reports. The first type accounts for approximately $60 \%$ of papers published; reviews $25 \%$, and case reports $15 \%$ (SalagerMeyer 1992).

11 Among these papers, a convenient starting point is the case report, the text-type which presents fewer difficulties both from the lexical and the syntactical point of view. In the absence of a specific structure the following format which includes the vital elements of research design has been suggested (Salager-Meyer 1991):

Case Presentation: Characteristics of the case/es dealt with by the article.

Findings: main results

Comments: short discussion about the findings and guidance on possible applications.

12 The third move is called Comments or Discussion because they are observations made on one or few patients only, and therefore they seldom state conclusions which can be generalized.

13 Review articles generally enunciate the results of bibliographical works. In these Data Identification, Study Selection, Data Extraction and Synthesis are fundamental moves. The reading material will be provided gradually, and will be varied and taken from the aforementioned text-types, although research articles will constitute the principal source. 

university of Los Andes in Merida, Venezuela. She published several partial results of this major research project. Statistical tests have enabled her to identify 1,425 roots, which form the core of medical English language, in a 100,000 word corpus of specialized medical articles and classify them into three strata: Basic Medical English (BME), Fundamental Medical English (FME), and Specialized Medical English (SME), (SalagerMeyer 1983). In relation to this work Bird (1984) has stated that a combined synchronic/ diachronic approach would result in a considerable reduction in the number of roots in the corpus. The previous division into lexical strata, although arrived at on a statistical basis, has nevertheless allowed the author to establish a strong relationship between: BME and Anglo-saxon (Germanic), FME and Latin SME and Greek roots has to be taken into account when we teach biomedical English to students with a mother tongue based on Latin, since the recognition of cognates may reduce learning and teaching tasks considerably (Salager-Meyer 1983). FME, which is denoted "sub-technical" or "academic vocabulary" by some researches, is the lexical stratum which poses greater difficulties since they are context-bound words and it is easier to learn a new word than to assimilate it with a meaning which is different to the usual one. Andrew Cohen et al. (1988) suggest teaching students different categories of sub-technical vocabulary -they call it "nontechnical"- as it is generally accepted that words which may lead to inappropriate interpretation often carry much of the meaning of scientific writing.

BME there is a greater frequency of terms derived from old German, the meaning of which may be unknown to our students. We have found that mentioning the Germanic word next to its classical correspondent is very useful.

Dubois published in 1988 the result of another study on lexical frequency carried out on the basis of 52 biomedical texts which allows the systematic use of the lists produced by those studies and involves grouping the verbs with the nouns, adverbs and adjectives in semantic fields. 

medical English literature to define the distinctive features and difficulties of this prose grammatical patterns include the compound nominal phrases, lexical structures which are not frequent in many languages and which do not allow a literal translation nor can they be transformed in simple sentences. Another study (Salager-Meyer 1987) examines the usage of infinitive clauses indicating the grammatical and rhetorical aspects of these particular structures which have to be taken into account when teaching biomedical English.

Major works on hedgings (Adams Smith 1984; Salager-Meyer 1991), have helped us to overcome the difficulties these terms pose for students when reading articles in medical journals, and in particular when the aim is to distinguish objective statements from author-marked observations and also the scale of intensity of related linguistic items.

21

We believe that the application of statistical methods to create lexical inventories for teaching purposes may be of great value. We have learned through experience that the consideration of specific distinctive features in scientific prose has helped our students to learn to read biomedical English effectively. Without doubt the improvement in reading is proportional to the amount read. Lectures alone are insufficient to enable real improvement, and therefore it is necessary to read outside the classroom. For this purpose we should use motivating material which may include articles on recent discoveries or controversial topics which are understandable both conceptually and linguistically.

We consider that if we teach the basic biomedical vocabulary and the particularly difficult or frequent syntax to our students, and we familiarize them with the formal structure of the different kinds of texts they may encounter, we will be providing them with the means to read efficiently the plethora of biomedical literature the Index Medicus compiles. The swift evolution of the Health related sciences forces professionals to a continuous formation and permanent retraining to keep up to date with the recent advances of their specialties.

\section{BIBLIOGRAPHY}

Adams Smith, D. E. 1984. “Medical discourse: Aspects of author's comment”. The ESP Journal 1, 1746.

Bird, N. 1984. "Problems in compiling lexical frequency lists. A case study in EMP”. EMP Newsletter 3/1, 30-35.

Cohen, A. et al. 1988. "Reading English for specialized purposes: discourse analysis and the use of students informants". Interactive Approaches in Second Language Reading. Cambridge: Cambridge University Press, 152-67.

Dubois, B.L. 1982. "The construction of noun phrases in biomedical journal articles". In Hoedt et al. (eds.), Pragmatics and LSP. The Copenhagen School of Economics. 
Dubois, B.L. 1988. "Classroom use of specialized lexicons, or what to do after the list arrives". EMP Newsletter 5/2, 20-31.

Johns T. \& Davies F. 1983. “Text as vehicle for information". Reading in a Foreign Language 1/1, 119.

Maher, J. 1987. “The development of English as an international language of medicine”. EMP Newsletter 4/1, 10-22.

Salager-Meyer, F. 1983a. "The lexis of fundamental medical English: Classificatory framework and rhetorical function (a statistical approach)". Reading in a Foreign Language 1/1, 34-64.

Salager-Meyer, F. 1983b. “Compound nominal phrases in scientific-technical literature: proportion and rationale”. In Pugh, A.K. \& J.M. Ulijn (eds.), Reading for Professional Purposes. London: Heinemann, 136-45.

Salager-Meyer, F. 1985. "Specialist medical English lexis: Classificatory framework and rhetorical function, a statistical approach". EMP Newsletter 2/2, 5-17.

Salager-Meyer, F. 1987. "Infinitive clauses in medical English literature: A rhetorico-grammatical approach”. EMP Newsletter 4/1, 23-33.

Salager-Meyer, F. 1991. Medical English: A scientific Reading Course. Merida, Venezuela: Universidad de los Andes.

Salager-Meyer, F. 1992. "A text-type and move analysis study of verb tense and modality distribution in ùedical English abstracts”. English for Specific Purposes 11, 93-113.

Swales, J. 1986. "Citation analysis and discourse analysis". Applied Linguistics 7/1. 1, 39-56.

Van Dijk, T. 1980. Macrostructures. Hillsdale, NJ: Erlbaum.

\section{ABSTRACTS}

The necessity of mastering both oral and written English has become indispensable in the field of the Health Sciences nowadays. Nevertheless the need for adequate allocation of time for language study is not always appreciated in many Faculties and Schools of Medicine. Consequently the aim of a number of English courses still is to teach reading biomedical English. There are three main types of medical prose: Text-books, Journals and Occupational. In this article the various patterns followed by different kind of texts are considered as well as their respective lexicons. Frequently occurring clauses, hedgings and other characteristics of English medical writing are also taken into account. In this respect we benefit from inventories, statistically determined in EMP research in the last decade.

Aujourd'hui, le besoin de dominer l'anglais écrit et oral est devenu indispensable pour les Sciences de la santé. Néanmoins, les Facultés de médecine ne consacrent pas assez de temps à l'enseignement de cette langue et, par conséquent, l'objectif de nombreux cours est encore la compréhension d'un texte écrit. Dans cette communication, on considère la différente organisation des principaux types de textes ainsi que le vocabulaire, la syntaxe, les hedgings et d'autres caractéristiques de cette prose scientifique. La recherche faite ces dernières décennies à propos l'EMP (English for Medical Purposes) a donné naissance à des glossaires, dont nous mentionnons les plus significatifs, pour les avoir trouvés intéressants en ce qui concerne la compréhension par la lecture. 
INDEX

Mots-clés: anglais médical, compréhension écrite

Keywords: biomedical English, reading comprehension

\section{AUTHOR}

LOURDES DIVASSON

University of La Laguna. Tenerife. Spain. lourdes.divasson@ull.es 